НАТАША В. ДАМЉАНОВИЋ ${ }^{1}$

ОШ “Аврам Мразовић”, Сомбор
ПРЕГЛЕДНИ ЧЛАНАК

UDK: 821.111-31 Lawrence D. H.

821.111-31 Forster E. M.

BIBLID: 0353-7129, 26(2021)2, p.269-278

\title{
LADY CHATTERLEY, HER LOVER AND THEIR ROOM WITH A VIEW - MODERNIST DISCOURSES ON LOVE AND REALITY
}

\begin{abstract}
Summary: The dawn of the 20th century in Britain witnessed changes in almost every aspect of women s everyday lives. The emergence of the women's movement and a new generation of female professionals transformed the traditional patriarchal social structure. The present paper pursues two main goals. First, it shows how the novels Lady Chatterley's Lover and A Room with a View emerged from this social-historical moment in Britain. Since the novels depict the period before the Great War, they connect two periods in English history: Victorianism and Modernism, two different ways of living and two different approaches to moral principles. The protagonists of the novels, Connie, later lady Chatterley, and Lucy, personify the young and impressionable women of that era. Second, the focus is on the layers of interpretation/the codes of meaning that indicate the narrative interface: similarities in the novels' plots and their characters. They also reflect on the social divide that marked the period. The paper also shows that, according to the story, plot, and discourse of the novels, money and social status cannot substitute for the bindings of love.

Keywords: Victorianism, Modernism, the new/modern woman, the layers of interpretation, the narrative interface, love
\end{abstract}

\section{INTRODUCTION}

The novels Lady Chatterley's Lover (1928) and A Room with a View (1908) were published during the same social-historical period in England. The emergence of the railway and that of the car as new means of transport altered people's perceptions of the world. The view gained from the train was moving, dynamic, temporal, and measurable. There is no still life in paintings and photographs; there are many pictures, one after the other, and not a grand static social tableau. Thus, trains construct

1ruza15@hotmail.com 
modernist plots. Forster, for example, in his novel sets "the plot in two geographically different points and the story is narrated through the narrative rhythm of a journey" (Zsélyi, 2003: 41). More importantly, it gave the writers the opportunity to travel and write about the world based on their personal experiences. Later on, the invention of the car endowed the writer, character, and plot with a feeling of power that is more personalized than the one gained via taking a train ride. It brought a new dimension into human life and, once more, altered perspectives. A new type of freedom based on the personal involvement of individuals emerged with the car.

The goal of this paper is to compare and contrast these two novels, which emerged as the consequence of the very same social-historical-technological changes in England. The mutual influence between D. H. Lawrence and E. M. Forster is shown in the narrative interface: similarities in the novels' plots and their characters. Life and freedom are the most important themes in these two novels. They are universal and close to every one of us. What's more, they are appealing for their timelessness.

Lady Chatterley's Lover and A Room with a View also depict the period before the Great War. They connect two periods in English history, that of Victorianism and Modernism. As a result, both novels mark a paradox: they are simultaneously progressive and regressive, modern and Victorian. Their analyses need to reflect this structural, thematic, and moral bias.

Next, despite all the technical progress, the difference between the classes was enormous. The profound social and economic gap was evident. Forster, for example, uses binary opposition to illustrate it. He divides characters into traditional and modern ones. As for Lawrence, he prefers another technique, a technique of dialect. Oliver, the character who represents the characters of the lower social class, very often uses the vernacular to stress the social gap between him and Lady Chatterley. Besides, the modern characters have to battle against moral and cultural repression throughout the novels to achieve their goals. The conventional or outdated ones are mostly presented with some mild irony. However, the question is whether the story, the plot, or the discourse conforms to Victorianism and Modernism, respectively. In Lady Chatterley's Lover, the husband's wound marks him unwillingly to remain a Victorian cliché: the hero who has defended his country, while Constance Chatterley's love blazons the lady's body and plot as that of a new/modern woman. In A Room with a View, the woman Lucy Honeychurch will also turn into with the guidance of Mr. Emerson. Lawrence and Forster frame the stories of Victorian heroism and travel within Modern/ist discourses that also counterpoint the stories.

Finally, the novels stress the possible negative consequences of the everlasting problem concerning female subjects. The protagonists, Connie, later Lady Chatterley, and Lucy Honeychurch, are young girls who are in conflict with the world they live in. Their anxiety and complete unwillingness to conform to the feminine ideals imposed by male expectations that dominated at the time are evident. On the one hand, they struggle against the marriage and relationship imposed on them by society. In doing so, they demonstrate a reaction to the seemingly unavoidable loneliness that is the out- 
come of the very same act. On the other hand, they long for a sincere, passionate touch and love liberated from social chains.

\section{THE NARRATIVE INTERFACE}

The mutual influence between D. H. Lawrence and E. M. Forster, two prominent and prolific writers, saw the light of day with these two novels. First of all, the similarity between the two of them is shown in the novels' plots. The themes, such as cultural and moral repression, freedom from institutional religion, growing up and the formation of identity in a period of transition, women's place in modern English society, repressed sexuality, and the meaning of true love, constitute a considerable segment of each novel's poetics. They also depict ambiguities that feature in this transitory era. These ambiguities influenced the formation of double plots in each novel: old and new, tradition and the individual's talent clashed, producing irony and metaphors. The ambiguity is also depicted via Lawrence and Forster's couples: Clifford-Oliver, Bertha-Connie, and Cecil-George, Lucy-Charlotte, respectively. The closure of each novel rearranges the characters. The new tableaux feature the Modern/ist personae and celebrate new love, new perspectives, new plots and desires that used to be repressed.

Both novels feature quite similar dramatis personae. In his book, Aspects of the Novel, Forster discusses two types of characters: the flat and the round ones. "Flat characters were called humorous, and were sometimes called types and sometimes caricatures" (Forster, 1956: 67). He also stresses that, in their purest form, they are created around a single idea or quality. The most important features of flat characters are that they are easily remembered by the reader afterwards and that they are easily recognized whenever they come in. When they bear more than one distinctive feature, we get the beginning of the curve towards the round ones. As far as round characters are concerned, Forster points out that "[...] they have been defined by implication" (Forster, 1956: 77). Bearing in mind this division, both writers divided the characters into conservative (the flat) or modern (the round) ones.

The Beadekker, which is associated with Charlotte, E. M. Forster uses to depict the narrow-minded middle-class English tourists. In the novel $A$ Room with a View, this class is represented by the characters of Miss Bartlett and Cecil Vyse, and their counterparts, Mrs. Bolton and Clifford, respectively, in the novel Lady Chatterley's Lover. On the other hand, the modern ones are characterized by their open approach to everything new and their implication. Their thinking is based on science rather than on religious dogma and expectations. They change over time and consequently shape the plot. In light of this, the genuine round characters in A Room with a View are: Lucy, George, and Freddy, and their counterparts are Connie, Oliver Mellors, and Hilda in the novel, Lady Chatterley's Lover.

D. H. Lawrence and E. M. Forster chose Italy as the protagonists' wished-for dream destination and the locus of the pivotal changes in their lives. For the English writers of that period, it was a place of inexhaustible inspiration. D. H. Lawrence pic- 
tures the trip to Italy through the significance of the number seventeen. Here, in this novel, it is used twice. First, 1917, the year when Connie and Clifford got married. After that, 17 June, when she left him and went to Italy. In E. M. Forster's novel, the first part and the last one take place in Italy. The last chapter repeats the first one, and at the same time, it is a reversal of its plot. The fight about the room at the beginning of the novel immediately links two couples. The difference between the two rooms is emphasized by the fact that while in one of the two rooms, people desire something which those in the other room have access to. Although Mr. Emerson and his son George, and Charlotte and Lucy have different principles and ideas, they will stay together till the end.

Finally, both novels talk about homosexuality. Contrary to D. H. Lawrence, E. M. Forster keeps his and the homosexuality of his characters hidden. The writers share the opinion that being in a closet ${ }^{2}$ is not the right solution to the problem, neither for men nor for women. It might have been the case that both writers described, through their characters, their own inner struggle, concerning sexuality. In the novel, Lady Chatterley's Lover, Lawrence pictures this issue through the character of Oliver Mellors, a gamekeeper on Clifford Chatterley's estate, Wragby. He is aloof, sarcastic, intelligent and noble. His sexual life is quite rich and diverse. He had his first relationship when he was sixteen. He seems to possess the charisma that women love, but "the serpent in the grass was sex" (Lawrence, 2005: 176). When he got rejected by Bertha, his first wife, he went to war, and there he started a new relationship, but this time with a man. In the novel $A$ Room with a View, Forster pictures the same topic through two characters: Freddy, Lucy's brother, and, above all, through Mr. Beebe. References to same-sex attraction are covert. Mr. Beebe, the rector, is a bookworm and a spiritual guide, the one who verifies and forbids. But at the same time, he is a closeted gay person. Though he is mostly firmly on the side of youth, love, and happiness in the novel, his character takes an interesting turn at the end. The bathing scene reveals important things concerning Mr. Beebe and Freddy, their feelings towards other men. Mr. Beebe becomes aware of the profound love he feels for George. He succeeds in hiding it from the others up to the moment when he hears that George and Lucy are planning to get married. After that, he quits any further contact with them.

\section{The concept of femininity}

The beginning of the $20^{\text {th }}$ century witnessed changes in almost every aspect of women's everyday lives, from the domestic sphere to the public. It is impossible not to notice the coincidence of the invention of the SHE-CAR with the emergence of the movement fighting for SHE/HER-RIGHTS. The women's movement, with its emphasis on advocacy of equal rights the rise of a new generation of female artists, photographers, and professionals transformed the traditional patriarchal social structure across the globe. Followed closely by the advent of World War I, these social shifts, which

2 "The closet is the defining structure for gay oppression in this century" (Sedgwick, 1990: 67). 
had been set in motion at the beginning of the century, developed further as women were propelled into the workforce, exposing them to previously male-dominated professional and political situations.

The early twentieth century was also a period when the "literary canon was dominated by men, and female writers often published under anonymous or male pseudonyms" (Mangan, 2019: 106). On the other hand, the plot that conformed to the masculine gaze began to lose its authority. It was replaced or sublimated by feminine discourses. So, the writers focused on the phenomenon of a new or modern woman. Lucy and Connie, personify the young and impressionable women who emerged during that era. They belong to the middle class and have an indefinite number of common characteristics. They are well educated, broad-minded, and full of life. They represent thousands of other women of the time who were frustrated by the limitations put on their sex. Lucy and Connie long for the room with a view which will reveal a romantic, exciting, and constantly changing landscape. The fact that both girls are Protestant defines the im/possibility for many things concerning life. The idea of freedom is deeply rooted in each of them. Connie travels abroad, meets different people, different customs and learns different languages. Lucy dreams of becoming a typist. She often speaks highly of herself. She has very clear goals and insists on her position in society. Moreover, they are both depicted as the never-dying vampire Medusa or Gorgon ${ }^{3}$. They have dark, curly hair and big, wondering eyes. They have a big body, a huge waist, and the appearance of a peasant woman with a husky voice. Namely, they are far from pretty enough to please the Victorian male gaze. The description of the huge waist symbolizes the Earth mother - Magna Mater: they can deliver as many children as they want to.

Their behavior is not the behavior of a medieval lady. Lucy constantly leans over the window, which is all but ladylike. While abroad, Connie has a sexual encounter with a student at the age of fifteen and loses her virginity. Therefore, the way they look on love is specific and different, too. Their urge to find the right gentleman, is strong. They support the idea that "[...] love ought to be for the advantage of both parties and for the injury of neither" (Phaedrus, 2008: 23). While they are in a relationship, Lucy with Cecil and Connie with Clifford, they live and make love with men who are more in love with an idea of what a woman is supposed to be rather than what/how a woman really is. Clifford and Cecil's ignorance, as well as the general sexual inexperience, are infinite. So much so, that they lead to ruining their lives. Their chivalrous behavior is neither enough nor something that either of the heroines expects from her lover/husband or, generally, from love.

3 "In Greek mythology, the Gorgons were three female monsters whose heads turned to stone anyone who looked at them. One of them, Medusa, was mortal" (Phaedrus, 2008: 78). 


\section{THE LAYERS OF INTERPRETATION/THE CODES OF MEANING}

In his seminal book $S / Z$, Roland Barthes discusses the importance of the code, a mirage of structure, and its role in a number of correlations between the world and the word. He claims that five different semiotic codes are common to all texts, and they "[...] create a kind of network, a topos through which the entire text passes (or rather, in passing becomes text)" (Barthes $S / Z, 1970: 20$ ). What's more, “[...] each code is one of the forces that can take over the text [...] one of the voices out of which the text is woven" (Barthes $S / Z, 1970: 21$ ). Barthes also says that since the meaning cannot come from the author, it has to be revealed in the process of textual analysis. Besides, there is always more than one way to read a text. With each re-reading, another meaning comes to the surface. Kaja Silverman, in her book The Subject of Semiotics, discusses Barthes' system of codes/layers of meaning. She points out that "[...] the greater the number and diversity of the codes which participate in the production of a given text, the more contradictory and unstable will be its play of signification" (Silverman, 1983: 241). Consequently, Kaja Silverman extends Barthes' system of codes/layers of meaning.

The iconic layer consists of the iconic signs, the things that represent real life. "The iconic sign resembles its conceptual object in certain ways. It may share certain of the properties which that object possesses, [...]" (Silverman, 1984: 19). This layer is represented by Connie's child and the wood near the family house. Connie's child will always remind her of her love for Oliver. As for the wood, that is the place loved and protected by Clifford. In this novel, it's the place of truth. In the other novel, the representation of the iconic layer is the accident in the Piazza Signoria. It's the place where heaven (Lucy) and earth (George) meet. It is the encounter that completes the narrative and begins the plot.

The organic or the biological layer represents everything that organically exists as a biological given: the tree, the human body, the grass, the sunshine, a cat. These all mark life in its biological sense. In the novel, Lady Chatterley's Lover, Oliver Mellors is the one who represents nature. His job connects with nature. His father was a collier, too. Even though Oliver spends some time in the army, he decides to go back and work as a miner. Above all, he helps Connie to become a mother. He is directly responsible for a new biologically given life. On the other hand, Freddy, Lucy's brother, is a student of anatomy. He is a nineteen-year old boy who occasionally looks "[...] at a bone which lay upon the piano (Forster, 1995: 67).

The metanarrative layer refers to a comprehensive explanation, especially in critical theory. It encourages signification itself and insists on truth. Clifford's aunt, Lady Bennerley, represents the metanarrative layer in the novel Lady Chatterley's Lover. She is a real lady who knows how things are going on in this family. With the four or five lines, Lady Bennerley gives the final shape to the plot when she tries to explain to Connie that the life she lives with Clifford is not real life. "[...] A woman has to live her life, or live to repent not having lived it" (Lawrence, 2005: 61). In doing 
so, she implies the truth of the narrative. In the novel, A Room with a View, Mr. Beebe shares the same qualities with Lady Bennerley. Both of them are the genuine implied authors of their narratives who insist on the truth. Mr. Beebe is polite, educated, and a gentleman in every sense of the word. He's certainly an intriguing and amiable character. We enjoy hanging out with him, but we never feel like we know him. He shares the secrets of the others, but he keeps his secrets only to himself.

The cultural layer provides us with rules according to which things are what they are meant to be. Namely, the cultural codes "speak the familiar truths of the existing cultural order, [...]" (Silverman, 1984: 242). In light of this layer, the novels Lady Chatterley's Lover and A Room with a View represent different sides of the very same coin. In other words, the very same thing is observed from the opposite angles, that of the male and female, respectively. Connie's father, Sir Malcolm Reid, is the one who fits this layer the best. He shares the opinion that extramarital affairs are an essential part of every marriage. He despises Clifford and the life that Clifford provides for Connie. Sir Malcolm Reid is a true representative of Victorian moral values and represents English culture from the male perspective. Charlotte, Lucy's older cousin, in the beginning, is a metaphor for Lucy's superego, but things change throughout the novel. She does her best to uphold what is called proper behavior. The Victorian postulates concerning women's behavior are deeply rooted in her. Among all the characters in the novel, she is the best representation of an endless battle between Victorian and modern moral values. Through Lucy, she achieves her eternal love, something that hasn't happened to her earlier. Charlotte is always present, by accident, whenever and wherever Lucy and George are together. In the end, she transforms from Lucy's superego into Lucy's unconscious and supports their love.

The hermeneutic layer is the most complicated one to understand "[...] since it implies a truth to be deciphered [...]" (Barthes, 1970: 75). The hermeneutic code has a function to "[...] set up delays (obstacles, stoppages, deviations) in the flow of the discourse;[...]" (Barthes, 1970: 75). Mrs. Bolton represents the hermeneutic layer in Lady Chatterley's Lover and Mr. Emerson in A Room with a View. They know a lot and pull the threads in their stories. For example, Mrs. Bolton was in love with Oliver Mellors once when she was young, so she is a pattern for Connie. On the other hand, the relation between Mr. Emerson and Lucy's cousin, which reappears/discloses in the last chapter, is the pattern for Lucy and George. Therefore, Mrs. Bolton is the one who reveals a secret relationship between Connie and Oliver whereas, Mr. Emerson is the one who supports and reveals the relation between Lucy and George in the novel A Room with a View.

The layer of transfer represents sublimation or displacement. It is one of "[...] the most important features of the dream-work. Displacement involves the transfer of psychic intensity from one to another; [...]" (Silverman, 1984: 62). So, transfer creates changes that may alter the course of the story. This layer in the novel Lady Chatterley's Lover is represented by the death of Clifford's brother, Herbert Chatterley. "In 1916 Herbert Chatterley was killed, so Clifford became heir [...]" (Lawrence, 2005: 7). In 
the novel, A Room with a View, the transfer happens with Lucy's fainting in the Piazza Signoria. It's a pivotal moment in the novel. Arriving at the piazza Signoria, where she meets George, she commits iconoclasm the moment she decides to buy the photographs of Florentine pictures. Those photographs emblematize the vanity of Victorianism against beauty and nature. Thus, this means that Lucy with this act assertively rejects cherished beliefs and established values and practices.

The mythic layer of interpretation is the older form of the cultural and "the symbolic code inscribes into literary and cinematic texts antitheses which are central to the organization of the cultural order to which they belong" (Silverman, 1984: 270). So, the symbolic code is important for the mythical layer, too. Concealment and repetition rule this layer. The mythic layer is divided into two modes of myth: the first one is the collective unconscious, and the second one is the personal myth of subjectivity. The segment that is closest to the collective unconscious is the unconscious, which is the repressed past. It is the part of the mind that controls consciousness and shows itself in a disguised form. It provides the text with the contrasting position of the primary and the secondary story. The primary story is the discourse of the unconscious, and it stimulates the secondary one. This layer of representation is depicted by Clifford and by George via their Oedipus complex ${ }^{4}$. The Oedipus complex is the trigger that stimulates the secondary story. However, the personal myth of subjectivity is represented by the superego. It provides ethics and burdens the subject with enigmas. In both novels, the superego is represented by the protagonists, Connie and Lucy. Although the superego can be thought of as a type of conscience that punishes misbehavior with feelings of guilt, both protagonists aim for perfection when it comes to love. Their love lives can be described through the concept known as compulsive repetition or repetition compulsion. In other words, if someone wants to, one has to repeat the actions one has been ashamed of. Compulsion is "[...] the manifestation of the power of the repressed" (Freud in Strachey, 1961: 14). In these two novels, Connie repeats (repetition) the adultery or runs from one lover to another (compulsion) while Lucy repeats/interchanges the kisses with George.

\section{Conclusion}

The greatness of the novels Lady Chatterley's Lover and A Room with a View is that they support and encourage the wheel of change in its early twentiethcentury operation. They promote and celebrate the introduction and popularization of technologies that have significantly altered the patterns of life. What's more, the writers D. H. Lawerence and E.M. Forster made a great deal of commentary on the historical, social, cultural, and moral issues of their age.

First of all, the novels depict and connect two periods in English history: Victorianism and Modernism, and, consequently, two different ways of living and two

4 "The Oedipal complex- noun [sing.] (psychology) feelings of sexual desire that a boy has for his mother and jealous feelings towards his father that he causes" (Hornby, 2005: 1051). 
different approaches to moral principles. These novels represent the bridge between a representation of a woman in England beaten by her husband with a stick no thicker than a man's thumb and a woman who has all the rights to make her own decisions. However, the English in both periods worried about the refinement and virtue of young girls.

These novels also depict a time of historical change when it comes to the everyday lives of women. At the time, women began to raise their voices. On the one hand, they did not support the idea that the world was observed via the male or phallic gaze, but on the other hand, they used it as a shred of evidence for their struggle. As for the male characters, both writers discuss the characters' secret lives and their affection for the same sex. In doing so, the writers also depict their inner preferences concerning it.

The layers of interpretation or the codes of meaning, show that the story can be read in different ways. Each re-reading helps us discover another meaning that does not necessarily appear on the surface. As a result, this method of reading and re-reading the same text provides us with a variety of meanings provided by each narrative. The layers of interpretation prove that there is now such a thing as truth. They point out all the hidden signs or simply the metaphors. They also show culturally and morally unacceptable behaviors, judged by those who proclaim them. Finally, the layers of interpretation/the codes of meaning used here indicate the similarity between the characters and their actions in these two novels.

In the end, analyzing the novels, one of my goals was to show that the novels Lady Chatterley's Lover and A Room with a View are much more than propaganda for sexual license and free love. The relationship between Connie and Clifford or Lucy and Cecil is the kind of relationship that is more conventional and fits social standards. The problem is that these same relationships are destroying their spirits. Although they lived in a period when living a life that is all mind was particularly true and popular among young members of the aristocratic class, they showed that they cannot live with the mind alone; they must also be alive physically.

\section{REFERENCES}

Barthes, R. (1974). S/Z. New York City, United States: Hill and Wang.

Ferber, M. (2007). A Dictionary of Literary Symbols. Cambridge, United Kingdom: Cambridge University Press.

Forster, E. M. (1956). Aspects of the Novel. New York, The USA: Harvest Books Publisher.

Forster, E. M. (1995). A Room with a View. Mineola, New York, The USA: Dover Publication Inc.

Hornby, A. S. (2005). Oxford Advantage Learner's Dictionary. New York, The USA: Oxford University Press.

Lawrence, D. H. (2005). Lady Chatterley's Lover. Hertfordshire, United Kingdom: Wordsworth Edition Ltd. 
Mangan, L. (2019). The Feminism Book: Big Ideas Simply Explained. London, Great Britain: Penguin Random House.

Phaedrus. (2006). Plato and Benjamin Jowett. Teddington, Middlesex, United Kingdom: The Echo Library.

Sedgwick, K. E. (1990). Epistemology of the Closet. California, The USA: University of California Press.

Silverman, K. (1983). The Subject of Semiotics. New York, The USA: Oxford University Press.

Strachey, J. (1961). Beyond the Pleasure Principle (S. Freud). New York, The USA: W. W. Norton \& Company.

Zsélyi, F. (2003). Semiotics_for_Cultural_Studies. Retrived from /https://www.academia.edu/2081365/.

\section{ЛЕЈДИ ЧЕТЕРЛИ, ЊЕН ЉУБАВНИК И ЊИХОВА СОБА СА ПОГЛЕДОМ - МОДЕРНИСТИЧКИ ДИСКУРСИ О ЉУБАВИ И СТВАРНОСТИ}

Резиме: Почетак двадесетог века у Енглеској карактеришу велике технолошке, историјске и друштвене промене. Истовремено јавља се феномен познатији као нова или модерна жена што постаје једна од најважнијих тема књижевности тога доба. Циљ овог рада је да укаже на две битне чињенице. Прво, оба романа Љубавник лејди Четерли и Соба $c$ погледом, настали су као последица истог историјског и друштвеног тренутка у Енглеској. Због чињенице да романи приказују период пре Првог светског рата, они последично повезују два периода енглеске историје: Викторијански период и модернизам, два различита начина живота и два различита приступа моралним принципима. Главне јунакиње романа Кони - касније лејди Четерли и Луси, оличење су младе, савремене жене тога периода. Друго, посебна пажња у раду посвећена је слојевима интерпретације/кодовима значења који помажу читаоцу да открије сличност заплета романа, сличност њихових ликова као и да укажу на класну поделу у Енглеској. Штавише, доказаћемо да, према причи, заплету и дискурсу романа, новац и друштвени статус не могу да надоместе задовољство које доноси љубав.

Кључне речи: Викторијански период, модернизам, нова/модерна жена, слојеви интерпретације, сличност заплета романа, љубав 